УДК 004.92: 744

Karpyuk L. V., Davydenko N. O.

\title{
INDEPENDENT WORK OF STUDENTS IN GRAPHIC DISCIPLINES AS A MEANS OF PRACTICAL-ORIENTED TRAINING IMPLEMENTATION
}

The article discusses the issues and problems of graphic learning of students, which they face during independent work. In modern conditions, technical universities need a new high-quality approach to the graphic training of students at various levels of education. A conscious attitude to self-study gives good results when using information and communication technologies and applying this knowledge. The established acute shortage of qualified engineering personnel at industrial enterprises can be overcome through practice-oriented training in cooperation with production. In the graphic training of engineering personnel, taking into account the realities of modern production, an objective need arose to develop new pedagogical technologies that provide an orientation towards innovative activities, the conscious setting of new creative tasks and the ability to solve these problems using modern professional methods. The spheres of mechanical engineering and construction at the present stage make high demands on university graduates in the field of vocational training simultaneously with the market demand for quick adaptation in the workplace, fulfillment of assigned production tasks and for further self-development and improvement of their professional skills. This, first of all, entrusts the universities that train engineering personnel with the task of finding new and optimizing existing teaching methods in the preparation of qualified specialists. Independent (distance learning can also be included here) is one of the modern vectors of development of the education system. This type of training meets the principles of modernity, accessibility and openness. The task of teachers is to create training courses containing all the necessary educational and methodological materials and forming competencies, regulated by the educational standard. The development of information technology provides additional opportunities for students of technical universities to obtain a deeper engineering education. One of the main tasks of modern education is to teach the student to independently work with new information, to constantly update their knowledge, increasing the level of graphic training necessary in the further practice of solving complex design problems. It is difficult to overestimate the importance of a student's independent work in the study of any science. But for part-time students, this work is fundamental. When entering the first year of the university for part-time education, students do not always have a clear idea of the complexity of part-time studies; they are often mistaken in thinking that teachers have lower requirements for knowledge and part-time students works .

Key words: robot self-reliance, master, test, graphic discipline, projection, graphic editor.

Introduction. Formation of personality at the present time of informatization and computerization is becoming the most important universal human task of our time. To solve it, society needs to bring the economy, politics, culture, spirituality and, at the same time, the education system to qualitatively new levels.

The development of information technology provides additional opportunities for students of technical universities to obtain a deeper engineering education. One of the main tasks of modern education is to teach the student to independently work with new information, to constantly update their knowledge, increasing the level of graphic training necessary in the further practice of solving complex design problems.

One of the conditions for the successful training of students in graphic disciplines is the organization of independent work. It is aimed at assimilating and consolidating educational material, and also develops a psychological attitude towards independent replenishment of one's knowledge, the ability to navigate in the flow of scientific information, i.e. is a condition for student self-organization and self-discipline in mastering knowledge.

The aim of article. For the organization of independent work of students at the Department of Mechanical Engineering and Applied Mechanics of V. Dahl Est Ukrainian National University, there are methodological aids for performing graphic works, as well as assignments in test form.

Working with tasks in the test form gives good results in the independent study of the graphic discipline where memorization of a large amount of theoretical material is required, as well as in preparing students for control and practical activities. Tasks are given in a certain sequence, due to the logic of the educational process, as well as the psychology of the students' assimilation of this discipline.

As the basis of the tasks, a logical form of expression was used, which allows to accurately express the content of the tasks, understandable for students and excluding the possibility of the appearance of erroneous answers based on substantive and formal characteristics.

The meaning of a textual statement, presented in the form of a simple declarative sentence, is always better understood than the meaning of a question. The search for the correct answer presupposes not only the reproduction of the knowledge gained, but also the creative comprehension of the proposed options, which contributes to the development of logical and spatial thinking and, as a consequence, the better assimilation of the material.

The main material. Before completing the assignments, it is necessary to repeat the lecture material and study the educational literature recommended by the teacher. You need to answer the test tasks in writing, writing down the corresponding answer opposite the task number. The answer can be a word, figure number, symbol, etc.

The assignments are presented in various forms. 
Tasks for which ready-made choices are given form the first form. The tasks of this form are divided into tasks with the choice of one correct answer and the choice of several correct answers. To answer the task, you need to choose one correct answer from the number offered in the task.

For example:

A horizontally projecting line is a straight line located to the projection plane $\mathrm{H}$ :

a) in parallel;

b) perpendicular;

c) at an arbitrary angle.

Answer: you should write: $b$.

Tasks with a choice of several answers are accompanied by the instruction «Select several correct answers».

For example:

Fastening screw connections include:

a) bolted;

b) hairpin;

c) keyway;

d) splined;

e) screw.

Answer: $\mathrm{a}, \mathrm{b}, \mathrm{d})$.

The second form includes tasks in which there is no ready-made answer. Tasks are preceded by an instruction consisting of one word - «Supplement». Such assignments are called open-ended assignments. Instead of dashes in tasks, you need to find the right word, symbol, number, etc.

For example:

The views that are projected onto the six faces of the cube are called

Answer: Basic.

The third form includes tasks in which it is necessary to assign elements of another set to the elements of one set. These assignments are called matching assignments. When answering such tasks, the test takers first select those pairs of elements that they know. And, if the number of components in the columns is the same, then the last pair of elements will be obtained by the method of sequential elimination. Therefore, one of the formal requirements for matching assignments is the unequal number of items in the right and left columns.

For example: Establish a correspondence between letter designations and the names of types of welded joints:
a) $\mathrm{C}$
1. butt;
b) $\mathrm{H}$
2. corner;
c) $\mathrm{T}$
3. T-shaped;
4. overlap.

Answer: $\mathrm{a}-1 ; \mathrm{b}-4 ; \mathrm{c}-3$.

The fourth form includes tasks to establish the correct sequence. These tasks help to solve the difficult task of forming the structure of knowledge. The purpose of introducing such tasks into the educational process is the formation of algorithmic thinking. An algorithm is a sequence of actions, the execution of which leads to the expected result. The unambiguity of tasks in the test form assumes the presence of only one algorithm. In the tasks for establishing the correct sequence, opposite each action, you need to put the corresponding numbers $(1,2,3$, 4, etc.).

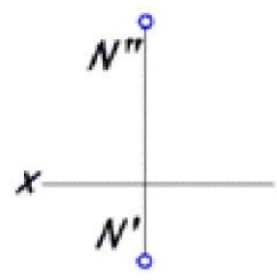

In the tests, the tasks of the second form are first given, for the successful completion of which it is necessary to learn all the concepts, definitions, and formulations. Then the tasks of the first form follow with the choice of one or more correct answers, which already require a comparative analysis of the educational material. To complete tasks of the following forms, it is necessary to build logical chains and algorithms for solving the tasks.

It is difficult to overestimate the importance of a student's independent work in the study of any science. But we must not forget about the students who study in the correspondence course. For part-time students, this work is fundamental. When entering the first year of the university for the correspondence course, students do not always have a clear idea of the complexity of studying in the correspondence department, they are often mistaken in thinking that teachers make lower requirements for knowledge and work done by correspondence students. When faced with reality, the student begins to realize that he was mistaken, but sometimes it is too late.

For the possibility of distance, self-study for students, there is an electronic course in the eCampus system. It is a course management system (e-learning), also known as a learning management system or virtual learning environment. It is a free web application that provides the ability to create sites for online learning (Figure 1) [2]. The course on 
computer and engineering graphics contains a working curriculum, guidelines for the implementation of practical, test works for correspondence students, electronic study guides, electronic lectures, graphic assignments, tests (Figure 1)

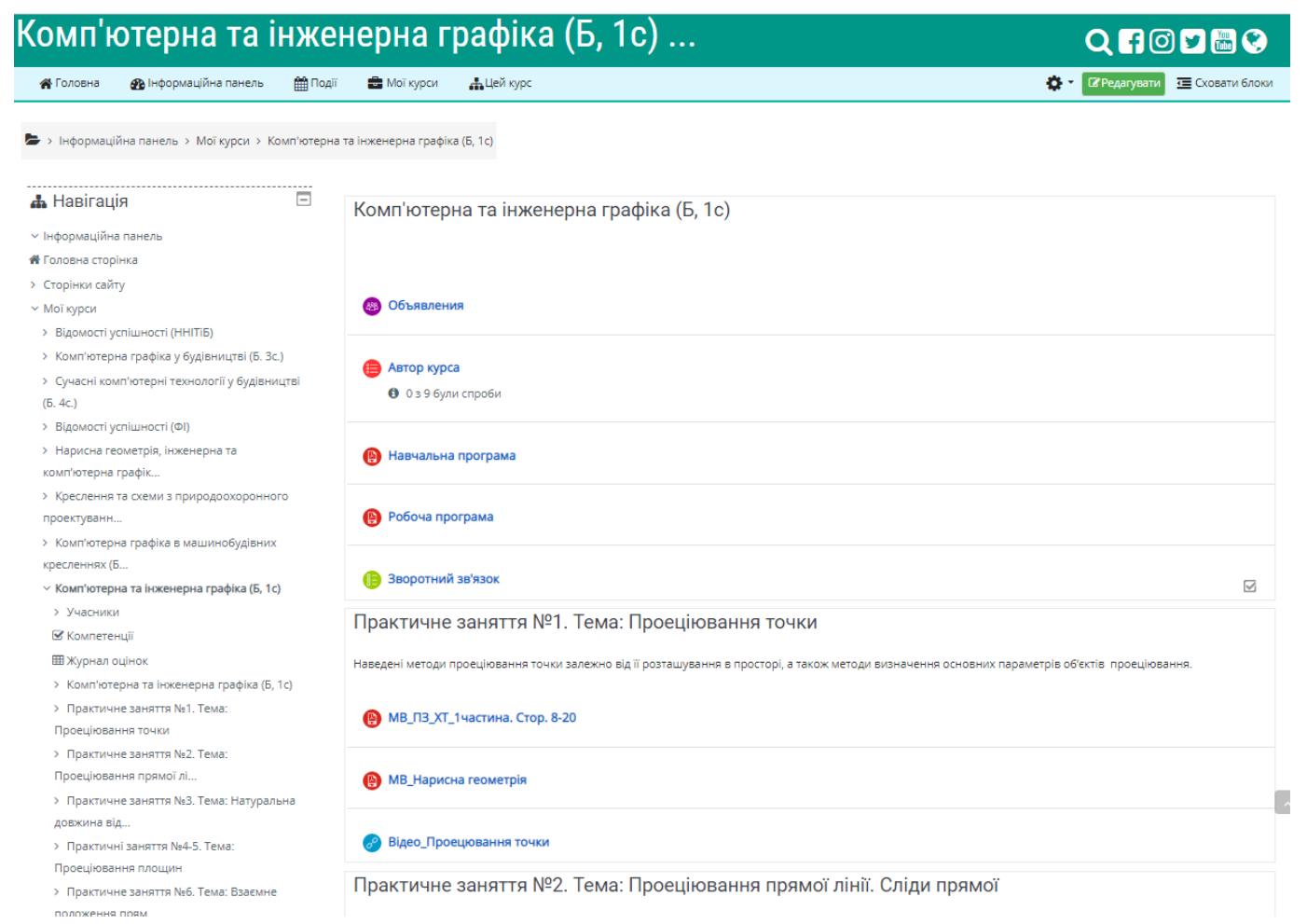

Figure 1 - Interface of the distance course system «Computer and engineering graphics»

In the eCampus system, the student has the opportunity to ask a question to the teacher, remotely submit drawings for verification, using three attempts. After checking each attempt, the student receives comments from the teacher about his work. The ability to remotely, at any convenient time, send drawings for verification is an absolute advantage. But a prerequisite for using eCampus for graphic disciplines is that the student has a graphic editor, and this is often an obstacle to using a distance course. Those students who do not know how to make a drawing electronically, often cannot understand the teacher's remarks, cannot formulate their question in writing. They did not understand and did not learn the special terms of descriptive geometry and engineering graphics, and ignorance of terms, like not knowing a foreign language, leads to misunderstanding between the student and the teacher [3, 4]. To exclude the possibility of passing other people's drawings and assessing knowledge, students, after correcting errors, must defend their work. To do this, you need to talk with the teacher and get answers to a number of questions about the constructions. During the interview, it immediately becomes clear whether the student himself has completed the graphic work. But even the fact that students are informed about the need to protect their drawings does not reduce the amount of plagiarism.

The quality of education is one of the most important criteria for the functioning of the education system. Assessment of the quality of education can be performed at different levels, by different means and according to different methods. A teacher often hears about the lack of time for students to complete assignments on time. But it has long been noted, learning requires desire and motivation, then there will be time.

Assistant in independent study of the discipline are all kinds of innovative methods. When checking the knowledge of students in those applied disciplines, the content of which provides for the development of any graphic software systems, for example, AutoCAD, it comes to the rescue using electronic testing systems. The focus is on tools that allow you to check your actual level of drafting / modeling skills.

The testing system is standard (i.e., non-specific, focused on general tasks), and, therefore, it does not include any specific assessment tools for graphic documents (drawings). Only those forms of test questions that are widely used.

So, let's analyze the forms of test questions offered to the teacher by the eCampus system. Here it is possible to create questions of the type: «Multiple-choice question», «Correct / incorrect», «Correspondence», «Short answer», «Numerical answer», «Essay», «Attached answers», «Identify missing words», etc. (Figure 2). 


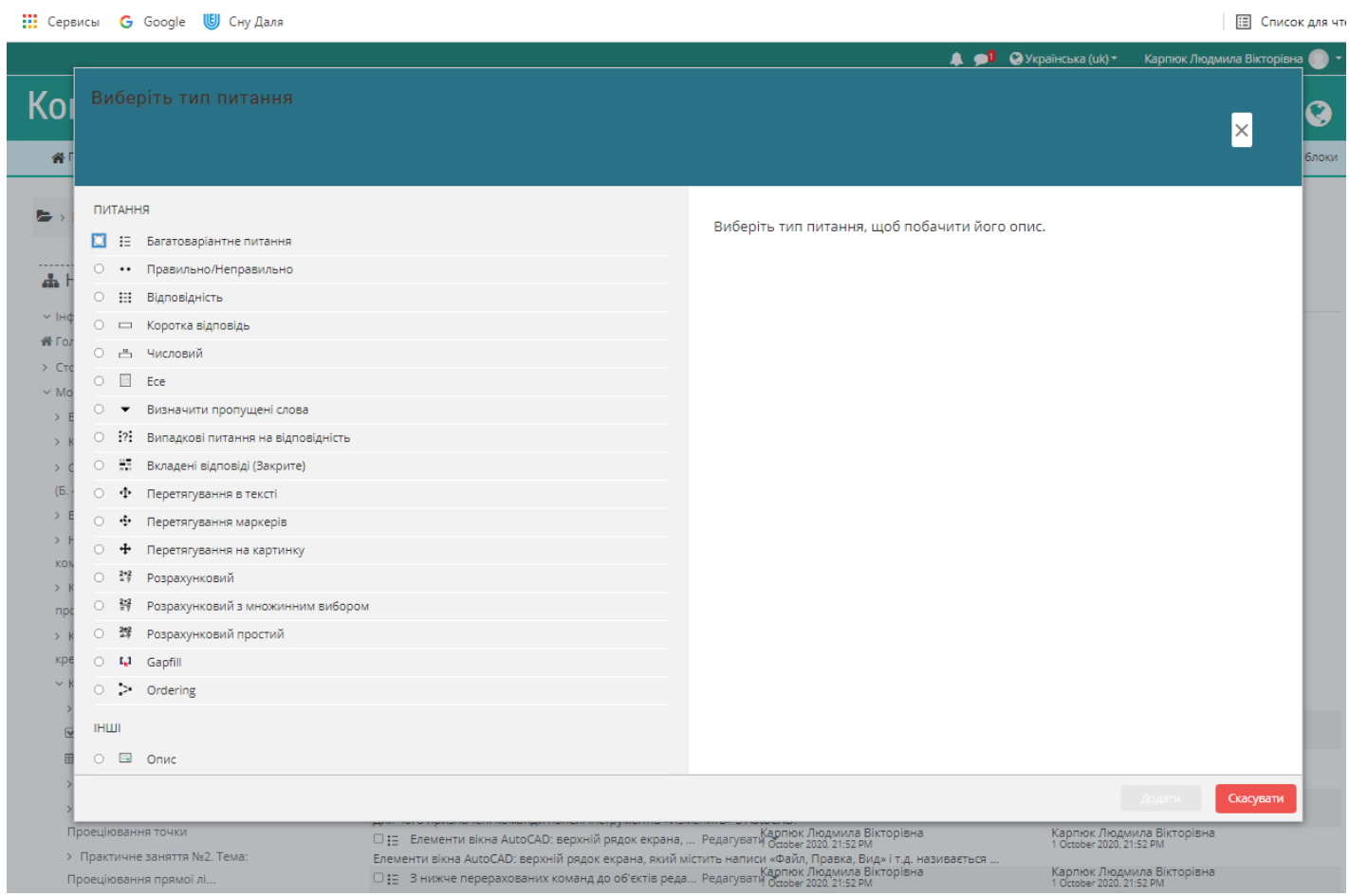

Figure 2 - Creating tests in the eCampus system

Almost any type of question can be used to test theoretical knowledge. The type of question «Short answer» is the most acceptable for assessment of graphic skills.

The general idea is: the task is to solve a graphic problem, draw a flat contour or create a model of a part according to the condition, then the student must perform measuring operations (measure length, cross-sectional area or shape, body volume, etc.) and enter the result in the field «the answer». In this case, the graphic / model part of the task can be performed in almost any software package (AutoCAD, COMPASS, SolidWorks, etc.), in some cases, even manually (in pencil).

This method of conducting current control is very effective at certain stages of training [2, 5]. For example, the tasks shown in Figure 3 and their various variations are used to test skills in Relative and Polar Coordinates in AutoCAD and Using Object Binding Mode in AutoCAD.
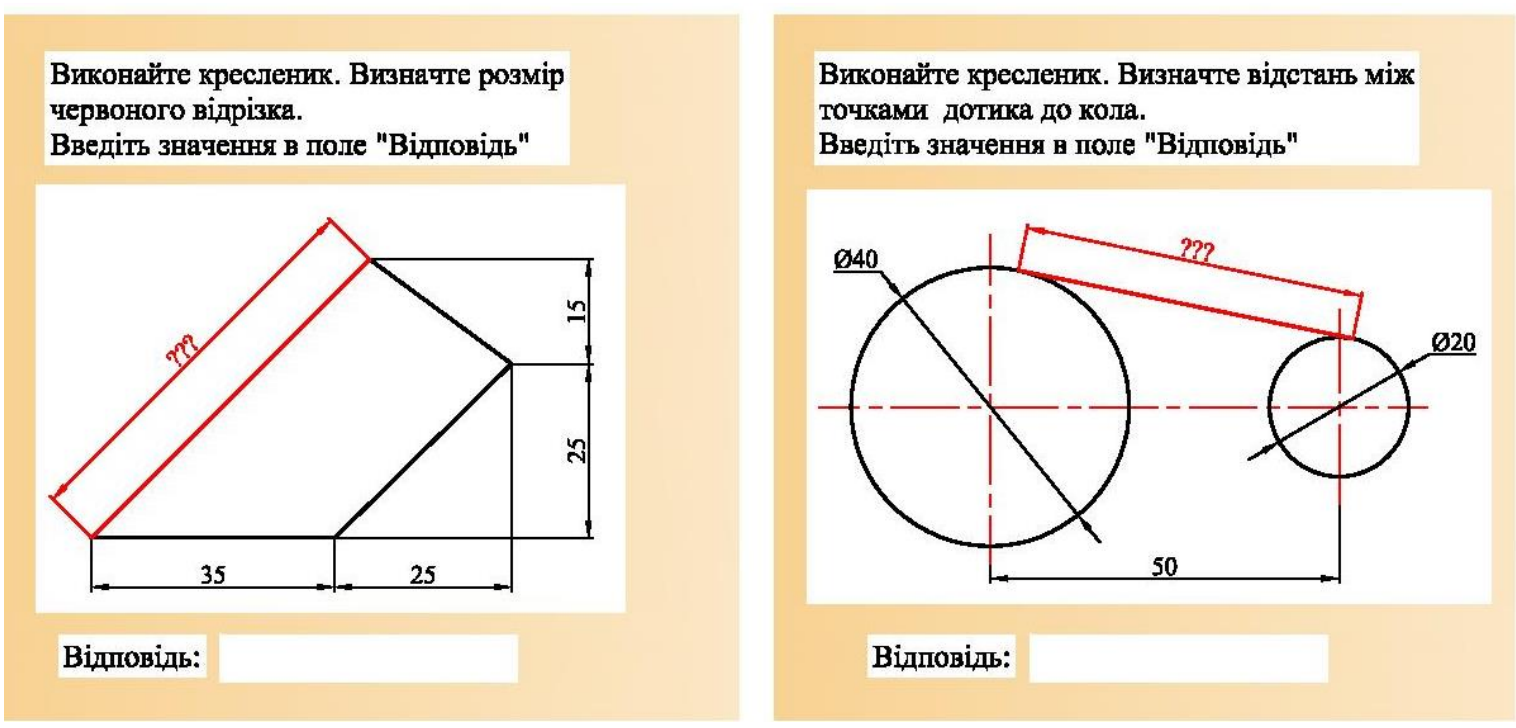

Figure 3 - Example of a graphical test task in AutoCAD.

Theme "Relative and polar coordinates" and the theme "Object bindings"

Conclusions. In conclusion, we can say that in the independent study of the material testing, conducted using electronic systems, has a number of indisputable advantages: first, the ability to work simultaneously with a large number of students; second, almost complete automation of the verification procedure; third, the efficiency and 
automatic generation of a report on learning outcomes in the form of logs and tables. The disadvantages of this method of control include: the high complexity of developing a database of test tasks, the specificity of control, a narrow range of topics covered.

Unfortunately, sometimes students come to the university for a diploma, not for knowledge. This problem is acute everywhere, one of the options for its solution is the right motivation of students, the educational work of the teacher, it is necessary to encourage students to educational activities to achieve educational goals. Only in this case a person will be a cool and competitive specialist.

\section{Ref e r e n e s}

1. Inzhenerna grafika. Navchal`ny`j posibny`k dlya samostijnoyi roboty` studentiv vsix form navchannya : Navchal`ny`j posibny`k / A. V. Shevchenko, S. I. Suxorukov, O. V. Tkachenko. - Vinny`cya : VNTU, 2009. - 174s.

2. Organizaciya osvitn`ogo procesu iz zastosuvannyam texnologij dy`stancijnogo navchannya u 2020/2021 navchal`nomu roci : metody`chni rekomendaciyi / Za zag. red. V. I. Shulyara. - My`kolayiv : OIPPO, 2020. - 108 s.

3. V. V. Vanin, N. V. Bily`cz`ka, O. G. Get`man, N. V. Mixlevs`ka. Nary`sna geometriya ta inzhenerna grafika. Navchal`ni zavdannya dlya programovanogo navchannya. Navchal`ny`j posibny`k dlya studentiv nemexanichny`x special`nostej.— K.: NTUU «KPI», 2020. - 69 s.

4. Nary`sna geometriya ta inzhenerna grafika $z$ kompetentnisny`m pidxodom : navchal`ny`j posibny`k / N. P. Znamerovs`ka. - Xerson : XDMA, 2020. - 236 s.

5. Komp'yuterna grafika v mashy`nobudivny`x kreslennyax:/ Ukl. L. V. Karpyuk, M. I. Gulida, S. A. Revenko. Navch. posibny`k. - Lugans`k: Vy`d-vo Sxidnoukrayins`kogo nacional`nogo universy`tetu imeni Volody`my`ra Dalya, 2007. -132 s.

\section{Література}

1. Інженерна графіка. Навчальний посібник для самостійної роботи студентів всіх форм навчання : Навчальний посібник / А. В. Шевченко, С. І. Сухоруков, О. В. Ткаченко. - Вінниця : ВНТУ, 2009. - 174с.

2. Організація освітнього процесу із застосуванням технологій дистанційного навчання у 2020/2021 навчальному році : методичні рекомендації / За заг. ред. В. І. Шуляра. - Миколаїв : ОІППО, 2020. - 108 с.

3. В. В. Ванін, Н. В. Білицька, О .Г. Гетьман, Н. В. Міхлевська. Нарисна геометрія та інженерна графіка. Навчальні завдання для програмованого навчання. Навчальний посібник для студентів немеханічних спеціальностей.— К.: НТУУ «КПІ», 2020. — 69 с.

4. Нарисна геометрія та інженерна графіка 3 компетентнісним підходом : навчальний посібник / Н. П. Знамеровська. - Херсон : ХДМА, 2020. - 236 с.

5. Комп’ютерна графіка в машинобудівних кресленнях:/ Укл. Л. В. Карпюк, М. І. Гуліда, С. А. Ревенко. Навч. посібник. - Луганськ: Вид-во Східноукраїнського національного університету імені Володимира Даля, 2007. -132 c.

У статті розглядаються питання і проблеми графічного навчання студентів, з якими вони стикаються під час самостійної роботи. В сучасних умовах в технічних вузах необхідний новий якісний підхід до графічної підготовки студентів різних рівнів навчання. Усвідомлене ставлення до самопідготовки дає хоромі результати при використанні інформаційно-комунікаційних технологій та застосуванні ичх знань. Гострий дефіцит кваліфікованих інженерних кадрів, щуо встановився на промислових підприємствах, може бути подоланий за рахунок практико-орієнтованого навчання у взаємодії з виробництвом. У графічній підготовиі інженерних кадрів з урахуванням реалій сучасного виробництва виникла об'єктивна необхідність розробки нових педагогічних технологій, щу забезпечують орієнтацію на інноваційну діяльність, усвідомлену постановку нових творчих завдань $i$ здатність вирімувати иі завдання сучасними професійними методами. Сфери машинобудування, будівництва на сучасному етапі висувають до випускників ВНЗ високі вимоги в області професійної підготовки одночасно з вимогою ринку до ивидкої адаптації на робочому місиі, виконання поставлених виробничих завдань $і$ до подальшого саморозвитку і підвищенню своїх професійних навичок. Це, перш за все, покладає на ВНЗ, які здійснюють підготовку інженерних кадрів, завдання з пошуку нових $i$ оптимізачії вже існуючих методів навчання при підготовці кваліфікованих фахівців. Самостійне (сюди ж можна включити і дистанційне) навчання є одним із сучасних векторів розвитку системи освіти. Даний вид навчання відповідає принципам сучасності, доступності та відкритості. Завдання педагогів - створення навчальних курсів, щзо містять всі необхідні навчально-методичні матеріали $i$ формують компетениії, регламентовані освітнім стандартом. Розвиток інформаційних технологій надає додаткові можливості для отримання більи глибокої інженерної освіти студентами технічних вузів. Одна з основних завдань сучасної освіти - навчити студента самостійно працювати з новою інформаџією, постійно оновлювати свої знання, підвищуючи рівень графічної підготовки, необхідної в подальшій практиці вирішення складних конструкторських завдань. Важко переоцінити значення самостійної роботи студента у вивченні будь-якої науки. Але для студентів-заочників ия робота є основною. Поступаючи на перший курс університету на заочну форму навчання, студенти не завжди мають чітке уявлення про складність навчання на заочній формі 
навчання, часто помиляються, думаючи, щзо викладачі пред'являють більш низькі вимоги до знань і робіт заочників.

Ключові слова: самостійна робота, завдання, тести, графічні дисичиліни, проекиії, графічний редактор.

В статье рассматриваются вопросы и проблемы графического обучения студентов, с которыми они сталкиваются во время самостоятельной работьл. В современных условиях в технических вузах необходим новый качественный подход к графической подготовке студентов различных уровней обучения. Осознанное отношение $\kappa$ самоподготовке дает хорошие результать при использовании информационнокоммуникационных технологий $и$ применении этих знаний. Установивщийся острый дефицит квалифицированных инженерных кадров на промышленных предприятиях может быть преодолен за счет практико-ориентированного обучения во взаимодействии с производством. В графической подготовке инженерных кадров с учетом реалий современного производства возникла объективная необходимость разработки новых педагогических технологий, обеспечивающих ориентацию на инновационную деятельность, осознанную постановку новых творческих задач и способность решать эти задачи современными профессиональными методами. Сферы машиностроения, строительства на современном этапе предъявляют $\kappa$ выпускникам ВУЗов высокие требования в области профессиональной подготовки одновременно с требованием рынка к быстрой адаптации на рабочем месте, выполнению поставленных производственных задач и к дальнейшему саморазвитию и повышению своих профессиональных навыков. Это, прежде всего, возлагает на ВУЗы, осуществляющие подготовку инженерных кадров, задачи по поиску новых и оптимизации уже существующих методов обучения при подготовке квалифицированных специалистов. Самостоятельное (сюда же можно включить и дистанционное) обучение является одним из современных векторов развития системы образования. Данный вид обучения отвечает принципам современности, доступности и открытости. Задача педагогов - создание учебных курсов, содержаших все необходимые учебнометодические материаль и формирующих компетенции, регламентированные образовательным стандартом. Развитие информационных технологий предоставляет дополнительные возможности для получения более глубокого инженерного образования студентами технических вузов. Одна из основньх задач современного образования - научить студента самостоятельно работать с новой информацией, постоянно обновлять свои знания, повышая уровень графической подготовки, необходимой в дальнейшей практике решения сложных конструкторских задач. Трудно переоценить значение самостоятельной работь студента в изучении любой науки. Но для студентов-заочников эта работа является основополагающей. Поступая на первый курс университета на заочную форму обучения, студенты не всегда имеют ясное представление о сложности учебы на заочной форме обучения, часто заблуждаются, думая, что преподаватели предъявяют более низкие требования к знаниям и сдаваемьм работам заочников.

Ключевые слова: самостоятельная робота, задания, тесты, графические дисциплины, проекции, графический редактор.

Lyudmila Karpyuk, senior lecturer of the Department of Mechanical Engineering and Applied Mechanics, Volodymyr Dahl East Ukrainian National University, e- mail: karp224@gmail.com

Nataliia Davydenko, senior lecturer of the Department of foreign languages and professional communication, Volodymyr Dahl East Ukrainian National University, e- mail: nat.davidenko11@gmail.com

Карпюк Людмила Вікторівна, старший викладач кафедри машинобудування та прикладної механіки СНУ імені В. Даля, е- mail: karp224@gmail.com

Давіденко Наталія Олександрівна, старший викладач кафедри іноземних мов та професійної комунікації СНУ імені В. Даля, е- mail: nat.davidenko11@gmail.com 